\title{
PERHITUNGAN PREMI MURNI PADA SISTEM BONUS MALUS UNTUK FREKUENSI KLAIM BERDISTRIBUSI BINOMIAL NEGATIF DAN BESAR KLAIM BERDISTRIBUSI WEIBULL PADA DATA ASURANSI KENDARAAN BERMOTOR DI INDONESIA
}

\author{
Rillifa Iris Adisti ${ }^{1 *}$, Aceng Komarudin Mutaqin ${ }^{2}$ \\ 1,2Prodi Statistika, Fakultas Matematika dan Ilmu Pengetahuan Alam, Universitas Islam Bandung \\ *email: rillifairis@gmail.com
}

\begin{abstract}
Systembonus malus is one of the systems offered by an insurance company where the risk premiumcalculation is based on the claim history of each policyholder. In study will be discussed premium calculation in system, bonus malus where the frequency of claims has a negative binomial distribution and the size of claims is Weibull distribution on motor vehicle insurance data in Indonesia. This method will producesystem an bonus malus optimal by finding the posterior distribution using Bayes analysis. As the application material used secondary data from the recording results obtained from the general insurance company PT. XYZ in 2014, data contains data on the frequency of claims and the amount ofclaims partial loss of policyholders forinsurance products for comprehensivemotor vehicle ins urance category 8 regions 3.The results of the implementation show that the premiums with the system are bonus malus optimalconsidered fair enough because the premiums paid by policyholders insurance that extends the policy in the following year is proportional to the risk it faces, where the premium to be paid by each policyholder is based on past claims history.
\end{abstract}

Keywords: system bonus malus, negative binomial distribution, Weibull distribution, comprehensive, partial loss.

\section{PENDAHULUAN}

Seiring dengan beragam dan banyaknya kendaraan bermotor yang beredar telah menimbulkan semakin padatnya kondisi lalu lintas dan risiko yang harus dihadapi oleh manusia. Risiko yang mungkin terjadi seperti kecelakaan dalam berkendara, dan hal lainnya yang merugikan bagi seseorang. Alangkah baiknya jika pengguna kendaraan memperhatikan risiko berkendara, solusi yang tepat untuk menanggulangi risiko tersebut sebaiknya pengguna kendaraan menyerahkan risiko tersebut kepada pihak asuransi. Asuransi atau pertanggungan menurut pasal 246 Kitab Undang-Undang Hukum Dagang (KUHD) adalah suatu perjanjian dengan mana seorang penanggung mengikatkan diri kepada seorang tertanggung, dengan menerima suatu premi, untuk penggantian kepadanya karena suatu kerusakan atau kehilangan keuntungan yang diharapkan yang mungkin akan dideritanya karena suatu peristiwa yang tidak tentu.

Salah satu jenis asuransi yang banyak diminati di Indonesia yaitu asuransi kendaraan bermotor, karena kendaraan bermotor merupakan salah satu barang investasi untuk kehidupan sehingga banyak masyarakat menggunakan perusahaan asuransi untuk mengalihkan risiko yang terjadi pada kendaraan bermotor mereka dari kejadian yang tidak diinginkan. Berbagai macam sistem yang ditawarkan oleh perusahaan asuransi untuk menarik minat masyarakat salah satunya adalah sistem bonus malus. Di Indonesia sistem bonus malus belum banyak digunakan, dan penggunaan hanya pada pemberian bonus bila tidak ada klaim selama setahun ketika perpanjang kontrak. Sistem bonus malus yang biasa digunakan biasanya hanya berdasarkan frekuensi klaim yang diajukan oleh pemegang polis tanpa memperhitungkan besar atau kecilnya klaim. Dalam hal ini pemegang polis yang 
mengajukan klaim akan membayar premi yang sama. Dengan cara ini pemegang polis yang mengalami kecelakaan kerugian dalam jumlah kecil akan membayar premi yang sama dengan pemegang polis yang mengalami kecelakaan kerugian dalam ukuran besar.

Secara umum ada dua jenis sistem bonus malus yang saat ini ada, yaitu sistem bonus malus didasarkan pada data frekuensi klaim saja dan sistem bonus malus yang didasarkan pada data frekuensi klaim dan data besar klaim. Dalam sistem bonus malus yang didasarkan pada data frekuensi klaim saja, frekuensi klaim dimodelkan oleh distribusi geometrik, binomial negatif, atau Poisson inverse Gaussian. Dalam penelitian (Mutaqin \& Komarudin, 2008) menjelaskan bahwa komponen dari frekuensi klaim menggunakan distribusi binomial negatif dapat menggunakan distribusi campuran dari distribusi Poisson dan distribusi gamma Sedangkan dalam sistem bonus malus yang didasarkan pada data frekuensi klaim dan data besar klaim, selain distribusi untuk frekuensi klaim yang disebutkan di atas, besar klaim dimodelkan oleh distribusi Pareto, atau Weibull.

Berdasarkan uraian di atas, dalam skripsi ini akan dibahas penerapan perhitungan premi pada sistem bonus malus dimana frekuensi klaim berdistribusi binomial negatif dan besar klaim berdistribusi Weibull untuk data asuransi kendaraan bermotor di Indonesia.

\section{TINJAUAN PUSTAKA}

\subsection{Sistem Bonus Malus}

Sistem Bonus Malus ini pertama kali diperkenalkan di Eropa pada awal tahun 1960 dan dikembangkan oleh Bichsel dan Bulhman tahun 1964 dan Delaporte pada tahun 1965. Sistem Bonus malus merupakan salah satu sistem yang ditawarkan oleh suatu perusahaan asuransi dimana dalam perhitungan premi risikonya berdasarkan sejarah klaim dari setiap pemegang polis. Dalam sistem ini jika pemegang polis melakukan klaim di tahun sebelumnya maka akan dikenakan malus yaitu meningkatnya jumlah premi yang harus dibayarkan untuk tahun berikutnya. Sebaliknya jika pemegang polis di tahun sebelumnya tidak melakukan klaim maka akan diberikan bonus yaitu pengurangan jumlah premi yang harus di bayar pada tahun berikutnya. Secara umum ada dua jenis sistem bonus malus yang saat ini ada, yaitu sistem bonus malus didasarkan pada data frekuensi klaim saja dan sistem bonus malus yang didasarkan pada data frekuensi klaim dan data besar klaim.

Dalam sistem bonus malus distribusi frekuensi klaim dimodelkan oleh distribusi binomial negatif yang merupakan distribusi campuran dari distribusi Poisson dengan parameter $\lambda$, dengan fungsi massa peluangnya adalah:

$$
P(X=k, \lambda)=\frac{e^{-\lambda} \lambda^{k}}{k !} \text {, untuk } k=0,1,2, \ldots
$$

Dimana parameter $\lambda$ berdistribusi gamma dengan parameter $r$ dan $\tau$.

$$
U(\lambda)=\frac{\tau^{r} e^{-\tau \lambda} \lambda^{r-1}}{\Gamma(r)}
$$

Distribusi marjinal dari $X$ dapat dihitung dengan menggunakan persamaan $P(X=k)=$ $\int_{0}^{\infty} P(X=k \mid \lambda) U(\lambda) d \lambda$ yang membentuk fungsi massa peluang untuk distribusi binomial negatif dengan parameter $r$ dan $\tau$ sebagai berikut:

$$
p_{k}=\left(\begin{array}{c}
k+r-1 \\
k
\end{array}\right)\left(\frac{\tau}{1+\tau}\right)^{r}\left(\frac{1}{1+\tau}\right)^{k}
$$

Misalkan $K_{1}, K_{2}, \ldots, K_{n}$ adalah suatu sampel acak berukuran $n$ dari distribusi binomial negatif dengan parameter $r$ dan $\tau$, dengan nilai sampel acak tersebut adalah Misalkan $k_{1}, k_{2}, \ldots, k_{n}$. Penaksir kemungkinan maksimum untuk $r$ dan $\tau$ dari distribusi binomial negatif tidak dapat diselesaikan secara ekspilit, namun hanya dapat ditaksir dengan 
menggunakan numerik. Salah satu metode numerik tersebut adalah metode NewtonRaphson. Taksiran parameter $r$ dan $\tau$ adalah solusi dari 2 persamaan berikut:

$$
\begin{aligned}
& n \ln \left(\frac{1+\tau}{\tau}\right)=\sum_{i=1}^{n} \sum_{j=0}^{k_{i}} \frac{1}{r+j} \\
& \tau=\frac{r}{\bar{k}}
\end{aligned}
$$

Distribusi besar klaim sering dimodelkan dalam asuransi kerugian. Besar klaim adalah besarnya pembayaran yang diberikan oleh perusahaan asuransi untuk menggantikan kerugian yang di klaim oleh pemegang polis asuransi. besarklaim dimodelkan oleh distribusi Weibull. Distribusi Weibull merupakan distribusi campuran dari distribusi eksponensial yang memiliki fungsi densitas peluang:

$$
f(x \mid \theta)=\theta e^{-x \theta} ; \quad 0<x<\infty \text { dan } \theta>0
$$

Parameter $\theta$ berdistribusi Levy dengan parameter $c$, dengan fungsi densitas peluang berikut:

$$
U(\theta)=\frac{c}{2 \sqrt{\pi \theta^{3}}} e^{-\frac{c^{2}}{4 \theta}} ; \theta>0
$$

Santi dkk. (2016) membahas distribusi marjinal dari $X$ dapat dihitung dengan menggunakan persamaan $f(x)=\int_{0}^{\infty} f(x \mid \theta) U(\theta) d \theta$ yang membentuk fungsi densitas peluang untuk distribusi Weibull:

$$
f_{x}(x)=\frac{1}{2} c x^{-\frac{1}{2}} e^{-c \sqrt{x}} ; s 0<x<\infty
$$

Fungsi distribusi kumulatif untuk distribusi Weibull di atas adalah:

$$
F(x)=1-e^{-c \sqrt{ } x} ; 0<x<\infty
$$

Misalkan $X_{1}, X_{2}, \ldots, X_{n}$ adalah suatu sampel acak beridistribusi Weibull sebagai distribusi campuran, dengan nilai sampel acak tersebut $x_{1}, x_{2}, \ldots, x_{n}$. Berdasarkan Persamaan (7) dapat dirumuskan taksiran parameter dari distribusi Weibull sebagai distribusi campuran menggunakan metode kemungkinan maksimum. Turunan fungsi loglikelihood terhadap parameter $c$ untuk data di atas adalah:

$$
\frac{\partial l(x, c)}{\partial c}=\frac{n}{\sum_{i=1}^{n}\left(x_{i}\right)^{\frac{1}{2}}}
$$

\subsection{Uji Kecocokan Distribusi}

\section{a. Uji kecocokan Chi Kuadrat}

Uji kecocokan chi kuadrat adalah suatu pengujian hipotesis statistik yang digunakan untuk mengetahui apakah $x_{1}, x_{2}, x_{3}, \ldots, x_{n}$ merupakan realisasi dari sampel acak $X_{1}, X_{2}, X_{3}, \ldots, X_{n}$ yang berasal dari distribusi $F($.$) . Pada uji kecocokan digunakan hipotesis$ sebagai berikut:

$H_{0}: x_{1}, x_{2}, x_{3}, \ldots, x_{n}$ merupakan realisasi dari sampel acak yang berdistribusi $F($.

$H_{1}: x_{1}, x_{2}, x_{3}, \ldots, x_{n}$ merupakan realisasi dari sampel acak yang berdistribusi bukan $F($.

Statistik uji untuk menguji kecocokan chi-kuadrat, yaitu:

$$
\chi^{2}=\sum_{i=1}^{k} \frac{\left(O_{i}-E_{i}\right)^{2}}{E_{i}}
$$


Nilai kritis dihitung dari distribusi chi-kuadrat dengan derajat bebas $k-p-1$, dimana $k$ banyaknya kategori dan $p$ banyaknya parameter dalam distribusi diskrit. Kriteria pengujiannya adalah tolak hipotesis nol jika statistik uji chi-kuadrat lebih besar dari nilai distribusi chi-kuadrat pada taraf nyata $\alpha$ dan derajat bebas $k-p-1$ atau $\chi^{2} \geq$ $\chi_{(k-p-1)(1-\alpha)}^{2}$

\section{b. Uji Kolmogorov-Smirnov}

Uji Kolmogorov-Smirnov merupakan salah satu uji kecocokan model untuk peubah acak kontinu. Hipotesis uji Kolmogorov-Smirnov adalah:

$H_{0}$ : Data berasal dari suatu populasi berdistribusi $F($.

$H_{1}$ : Data tidak berasal dari suatu populasi $F($.

Misalkan suatu sampel acak berukuran $n$, yaitu $X_{1}, X_{2}, \ldots, X_{n}$, dimana realisasi dari sampel acak tersebut adalah $x_{1}, x_{2}, \ldots, x_{n}$. Statistik uji Kolmogorov-Smirnov untuk hipotesis di atas adalah:

$$
D=\max _{1 \leq i \leq n}\left|F_{n}\left(x_{i}\right)-F^{*}\left(x_{i}\right)\right|
$$

Hipotesis nol diterima apabila statistik uji $D$ lebih kecil dari nilai kritisnya, maka nilai kritis untuk uji hipotesis di atas dapat dilakukan dengan nilai pendekatan $n$ yang disajikan dalam Tabel 1.

Tabel 1 Nilai Kritis Uji Kolmogorov-Smirnov untuk n > 25

\begin{tabular}{|c|r|r|r|}
\hline Tingkat Signifikansi $(\boldsymbol{\alpha})$ & 0,10 & 0,05 & 0,01 \\
\hline Nilai kritis & $\frac{1,22}{\sqrt{n}}$ & $\frac{1,36}{\sqrt{n}}$ & $\frac{1,63}{\sqrt{n}}$ \\
\hline
\end{tabular}

\subsection{Sistem Bonus Malus Optimal}

Perhitungan premi risiko sistem bonus malus optimal yang wajib dibayarkan oleh setiap pemegang polis asuransi didasarkan pada komponen frekuensi klaim dan besar klaim yang diajukan oleh pemegang polis asuransi. Model komponen dari frekuensi klaim menggunakan distribusi binomial negatif yang merupakan campuran dari distribusi Poisson dan distribusi gamma. Dengan menggunakan pendekatan Bayes (Mutaqin \& Komarudin, 2008) diperoleh distribusi posterior untuk peubah acak $\lambda$ sebagai berikut:

$$
\lambda u\left(\lambda \mid k_{1}, k_{2}, \ldots, k_{t}\right)=\frac{e^{-\lambda(t+\tau)} \lambda^{K+r-1}(t+\tau)^{K+r}}{\Gamma(K+r)}
$$

Dengan menggunakan fungsi rugi kuadratik, taksiran rata-rata banyaknya klaim dari pemegang polis asuransi pada tahun $t+1$ adalah:

$$
\hat{\lambda}_{t+1}=E(\lambda \mid K)=\int_{0}^{\infty} \lambda u\left(\lambda \mid k_{1}, k_{2}, \ldots, k_{t}\right)=\frac{K+r}{t+\tau}
$$

dengan $K=\sum_{i=1}^{t} k_{i}$ menyatakan total frekuensi klaim selama $t$ periode dan $k_{i}$ menyatakan frekuensi klaim dari pemegang polis pada periode waktu ke-i, $i=1,2, \ldots, t$.

Misalkan $x_{i}, i=1,2, \ldots, K$, menyatakan besar klaim ke $i$, kemudian total besar klaim untuk seorang pemegang polis selama $t$ periode adalah $\sum_{i=1}^{K} x_{i}$. Distribusi posterior untuk parameter $\theta$ dapat diperoleh dengan menggunakan pendekatan Bayes sebagai berikut: 


$$
\pi\left(\theta \mid x_{1}, x_{2}, \ldots, x_{K}\right)=\frac{\theta^{K-\frac{3}{2}} e^{-\left(\frac{c^{2}}{4 \theta}+\theta\left(\sum_{i=1}^{K} x_{i}\right)\right)}}{\int_{0}^{\infty} \theta^{K-\frac{3}{2}} e^{-\left(\frac{c^{2}}{4 \theta}+\theta\left(\sum_{i=1}^{K} x_{i}\right)\right)} d \theta}
$$

Memodifikasi Persamaan (14), sehingga diperoleh:

$$
\begin{aligned}
& \pi\left(\theta \mid x_{1}, x_{2}, \ldots, x_{K}\right) \\
& \left(\frac{c}{2 \sqrt{\sum_{i=1}^{K} x_{i}}}\right)^{-\left(K-\frac{1}{2}\right)} \theta^{K-\frac{3}{2}} e^{-\left(\frac{c^{2}}{4 \theta}+\theta\left(\sum_{i=1}^{K} x_{i}\right)\right)}
\end{aligned}
$$

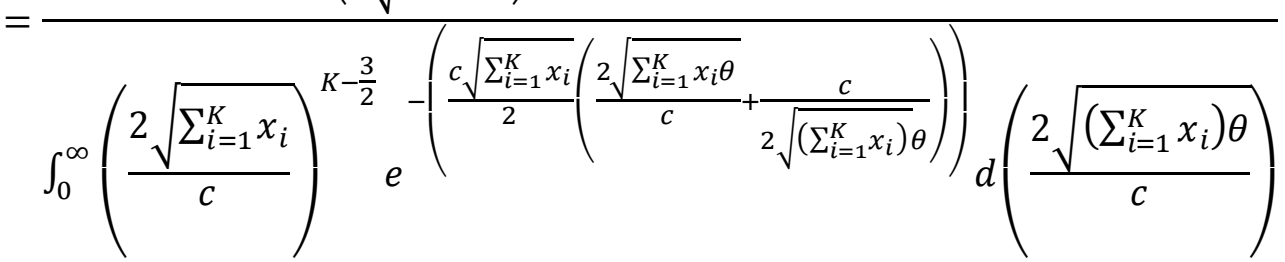

Bentuk integral pada Persamaan (15) dapat diselesaikan dengan menggunakan fungsi Bassel sehingga diperoleh:

$$
B_{v}(x)=\frac{1}{2} \int_{0}^{\infty} y^{v-1} e^{-\frac{x}{2}\left(y+\frac{1}{y}\right)} d y, B_{v}(x)>0, \forall x>0, v \in R .
$$

Maka distribusi posterior untuk besar klaim yaitu:

$$
\pi\left(\theta \mid x_{1}, x_{2}, \ldots, x_{k}\right)=\frac{\left(\frac{c}{2 \sqrt{\left(\sum_{i=1}^{K} x_{i}\right)}}\right)^{-\left(K-\frac{1}{2}\right)} \theta^{\left.K-\frac{3}{2} e^{-\left(\frac{c^{2}}{4 \theta}+\theta\left(\sum_{i=1}^{K} x_{i}\right)\right)}\right)}}{2 B_{k-\frac{1}{2}}\left(c \sqrt{\left(\sum_{i=1}^{K} x_{i}\right)}\right)}
$$

Estimasi rata-rata besar kerugian untuk periode selanjutnya $\theta_{t+1}$ menggunakan fungsi kerugian kuadratik, jika diketahui besar kerugian $x_{1}, x_{2}, \ldots, x_{k}$ selama periode waktu $t$ dan $K$ klaim adalah:

$$
\hat{\theta}_{t+1}=\frac{B_{K-\frac{3}{2}}\left(c \sqrt{\left(\sum_{i=1}^{K} x_{i}\right)}\right)}{B_{K-\frac{3}{2}}\left(c \sqrt{\left(\sum_{i=1}^{K} x_{i}\right)}\right)}\left(\frac{2 \sqrt{\sum_{i=1}^{K} x_{i}}}{c}\right)
$$

Jika premi risiko periode $t+1$ yang ditetapkan tidak hanya bergantung pada banyaknya klaim $k_{1}, k_{2}, \ldots, k_{t}$, tetapi juga bergantung pada ukuran klaim $x_{1}, x_{2}, \ldots, x_{k}$. Maka premi risiko yang harus dibayarkan oleh setiap pemegang polis adalah:

$$
\operatorname{premi}_{(t+1)}=\left(\frac{K+r}{t+\tau}\right) \frac{B_{K-\frac{3}{2}}\left(c \sqrt{\left(\sum_{i=1}^{K} x_{i}\right)}\right)}{B_{K-\frac{3}{2}}\left(c \sqrt{\left(\sum_{i=1}^{K} x_{i}\right)}\right)}\left(\frac{2 \sqrt{\sum_{i=1}^{K} x_{i}}}{c}\right)
$$


Pada saaat besar kerugian $=0$ atau pada saat tidak ada klaim yang diajukan $(K=0)$ perhitungan premi risiko pada Persamaan (19) tidak terdefinisi sehingga perlu dianalisis ulang. Analisis premi risiko untuk besar kerugian pada saat 0 adalah sebagai berikut:

$$
\operatorname{Premi}_{K=0}=\frac{r}{\tau}\left(\frac{2}{c^{2}}\right)
$$

\subsection{Asuransi}

Asuransi merupakan perjanjian antara dua pihak, yaitu perusahaan asuransi dan pemegang polis yang menjadi dasar bagi penerimaan premi oleh perusahaan asuransi sebagai imbalan untuk memberikan penggantian atas kerugian finansial yang dialami oleh tertanggung atau pemegang polis (UU. RI Nomor 40 tahun 2014 tentang Perasuransian).

Menurut Abdulkadir Muhammad (dikutif dalam Febriana, 2012) asuransi dapat diklasifikasikan dalam beberapa kriteria, yaitu:

1. Berdasarkan sifat perikatannya

2. Berdasarkan jenis resiko

3. Berdasarkan jenis usaha

\subsection{Asuransi Kendaraan Bermotor}

Asuransi kendaraan bermotor adalah produk asuransi kerugian yang melindungi tertanggung dari risiko kerugian yang mungkin timbul sehubungan dengan kepemilikan dan pemakaian kendaraan bermotor (Peraturan Menteri Keuangan Nomor 74/PMK.010/2007 tentang penyelenggaraan pertanggungan asuransi pada lini usaha asuransi kendaraan bermotor dalam pasal 1 ayat 2). Terdapat dua jenis perlindungan untuk asuransi kendaraan bermotor, yaitu:

1. Total Loss Only (TLO) atau Kerugian Total

2. Comprehensive (Komprehensif) atau Risiko Gabungan

\section{METODE PENELITIAN}

Data yang digunakan dalam skripsi ini adalah data sekunder hasil pencatatan yang diperoleh dari PT. XYZ tahun 2014. Data tersebut berisi frekuensi klaim dan besar klaim pemegang polis untuk produk asuransi kendaraan bermotor comprehenshive terhadap perusahaan asuransi PT XYZ. Data yang akan dipakai dalam keperluan aplikasi adalah data pemegang polis asuransi kendaraan bermotor kategori 8 yang terdapat pada Wilayah 3 .

\subsection{Metode Uji Kecocokan Distribusi Binomial Negatif}

Berikut ini adalah tahapan pengujian kecocokan distribusi binomial negatif untuk data frekuensi klaim asuransi kendaraan bermotor menggunakan uji kecocokan chi-kuadrat:

1. Merumuskan Hipotesis

$H_{0}$ : data frekuensi klaim berasal dari populasi berdistribusi binomial negatif.

$H_{1}$ : data frekuensi klaim bukan berasal dari populasi yang berdistribusi binomial negatif.

2. Menaksir parameter distribusi binomial negatif menggunakan metode iterasi Newton Raphson yang merupakan solusi dari Persamaan (4) dan (5). Perangkat lunak Matlab akan digunakan untuk menaksir parameter tersebut.

3. Menghitung taksiran peluang untuk setiap frekuensi klaim yang mungkin, $p_{x}$, untuk $x=$ $0,1,2, \ldots$ menggunakan Persamaan (3).

4. Menghitung statistik uji chi-kuadrat menggunakan Persamaan (10). 
5. Memutuskan apakah hipotesis $H_{0}$ ditolak atau diterima dengan membandingkan nilai statistik uji chi-kuadrat dengan nilai kuantil distribusi chi-kuadrat pada taraf nyata $\alpha$ dengan derajat bebas $k-3$, dimana $k$ adalah banyaknya kategori.

\subsection{Metode Uji Kecocokan Distribusi Weibull Sebagai Dis tribusi Campuran}

Berikut ini tahapan pengujian kecocokan distribusi Weibull sebagai distribusi campuran untuk data besar klaim asuransi kendaraan bermotor menggunakan uji kecocokan Kolmogorov-Smirnov:

1. Merumuskan Hipotesis

$H_{0}$ : data besar klaim berasal dari populasi berdistribusi Weibull sebagai distribusi campuran

$H_{1}$ : data besar klaim bukan berasal dari populasi yang berdistribusi Weibull sebagai distribusi campuran

2. Menaksir parameter distribusi Weibull sebagai distribusi campuran dengan menggunakan Persamaan (9).

3. Mengurutkan data besar klaim kendaraan bermotor dari nilai terkecil ke terbesar.

4. Menghitung fungsi distribusi empiris pada data pengamatan ke-i.

5. Menghitung fungsi distribusi kumulatif untuk distribusi Weibull sebagai distribusi campuran menggunakan Persamaan (8).

6. Menghitung nilai statistik uji Kolmogorov Smirnov menggunakan Persamaan (11).

7. Membandingkan nilai statistik uji dengan nilai kritis pada taraf nyata $\alpha$. Kemudian memutuskan apakah hipotesis nol diterima atau ditolak.

\subsection{Perhitungan Premi dengan Sis te m Bonus Malus Optimal}

Berikut ini adalah langkah-langkah menghitung premi murni menggunakan sistem bonus malus optimal:

1. Menghitung taksiran rata-rata banyaknya klaim pada tahun $t+1$ menggunakan Persamaan (13).

2. Menghitung taksiran rata-rata besar klaim pada tahun $t+1$ menggunakan Persamaan (18).

8. Menghitung taksiran premi asuransi kendaraan bermotor untuk periode $t+1$ menggunakan Persamaan (19), dengan menggunakan software Microsoft Excel.

9. Menghitung taksiran premi asuransi kendaraan bermotor pada saat tidak ada klaim yang diajukan $(K=0)$ menggunakan Persamaan(20), dengan menggunakan software Microsoft Excel.

\section{HASIL DAN PEMBAHASAN}

\subsection{Uji Kecocokan Distribusi Binomial Negatif}

Hipotesis pengujiannya adalah:

$H_{0}$ : Data frekuensi klaim asuransi kendaraan bermotor kategori 8 wilayah 3 di Indonesia berasal dari populasi yang berdistribusi binomial negatif.

$H_{1}$ : Data frekuensi klaim asuransi kendaraan bermotor bermotor kategori 8 wilayah 3 di Indonesia bukan berasal dari populasi yang berdistribusi binomial negatif

Selanjutnya adalah menghitung taksiran parameter distribusi binomial negatif dengan bantuan perangkat lunak Matlab R2018a Hasil taksiran parameter distribusi binomial negatifnya adalah $\hat{r}=0,04735$ dan $\hat{\tau}=4,26617$. Berdasarkan nilai taksiran parameter distribusi binomial negatif yang telah diperoleh, dapat dihitung nilai taksiran peluang untuk setiap frekuensi klaim menggunakan Persamaan (3). Secara umum nilai taksiran peluang untuk setiap kategori frekuensi klaim adalah: 
$p_{k}=\left(\begin{array}{c}k+\hat{r}-1 \\ k\end{array}\right)\left(\frac{\hat{\tau}}{1+\hat{\tau}}\right)^{\hat{r}}\left(\frac{1}{1+\hat{\tau}}\right)^{k}$

Hasil nilai taksiran peluang untuk setiap frekuensi klaim disajikan dalam Tabel 2 kolom (3), kolom (1) berisikan frekuensi klaim, kolom (2) berisikan banyaknya pemegang polis yang mengajukan klaim. Berdasarkan nilai taksiran peluang frekuensi klaim tersebut, dapat dihitung nilai harapan untuk setiap frekuensi klaim, $n p_{k}$, untuk setiap $k$, yaitu dengan mengalikan $p_{k}$ dengan ukuran sampel.

Nilai statistik uji chi-kuadrat ada dalam Tabel 2 kolom (5) baris terakhir, yaitu 0,0641. Dengan taraf nyata 5\% nilai kuantil distribusi chi-kuadrat dengan derajat bebas (43) adalah 3,84. Terlihat bahwa nilai statistik ujinya lebih kecil dibandingkan dengan nilai kuantilnya. Dengan demikian hipotesis nol diterima dan disimpulkan bahwa data frekuensi klaim pemegang polis asuransi kendaraan bermotor kategori 8 wilayah 3 berasal dari populasi berdistribusi binomial negatif.

Tabel 2 Nilai-nilai yang dibutuhkan untuk Perhitungan Statistik Uji Pada Distribusi Binomial Negatif

\begin{tabular}{ccccc}
\hline $\begin{array}{c}\text { Frekuensi } \\
\text { Klaim }\end{array}$ & $\begin{array}{c}\text { Banyaknya } \\
\text { Pemegang Polis }\end{array}$ & $\begin{array}{c}\text { Peluang } \\
\text { Terjadinya Klaim }\end{array}$ & $\begin{array}{c}\text { Nilai Harapan } \\
\text { Terjadinya Klaim }\end{array}$ & $\frac{\left(\boldsymbol{O}_{\boldsymbol{i}}-\boldsymbol{E}_{\boldsymbol{i}}\right)^{\mathbf{2}}}{\boldsymbol{\boldsymbol { E }}_{\boldsymbol{i}}}$ \\
\hline 0 & 5.888 & 0,9901 & $5.888,0574$ & 0,0000 \\
1 & 53 & 0,0089 & 52,8857 & 0,0002 \\
2 & 5 & 0,0009 & 5,2588 & 0,0127 \\
$\geq 3$ & 1 & 0,0001 & 0,7981 & 0,0511 \\
Jumlah & 5.947 & 1,0000 & 5.947 & 0,0641 \\
\hline
\end{tabular}

\subsection{Uji Kecocokan Dis tribusi Weibull}

Hipotesis untuk pengujian tersebut adalah:

$H_{0}$ : Data besar klaim asuransi kendaraan bermotor kategori 8 wilayah 3 di Indonesia berasal dari populasi yang berdistribusi Weibull sebagai distribusi campuran.

$H_{1}$ : Data besar klaim asuransi kendaraan bermotor kategori 8 Wilayah 3 di Indonesia bukan berasal dari populasi yang berdistribusi Weibull sebagai distribusi campuran.

Selanjutnya yaitu menghitung nilai taksiran parameter $c$ dari distribusi Weibull sebagai distribusi campuran. Nilai taksirannya dihitung berdasarkan Persamaan (7) yaitu:

$\hat{c}=\frac{n}{\sum_{i=1}^{n}\left(x_{i}\right)^{\frac{1}{2}}}=\frac{66}{148616,6}=0,0004$.

Berdasarkan nilai taksiran parameter $c$, dapat dihitung nilai taksiran fungsi distribusi kumulatif dari distribusi Weibull sebagai distribusi campuran. Misal untuk data urutan pertama, $x_{(1)}=101500$, dengan bantuan perangkat software Microsoft Excel 2013 diperoleh nilai taksiran fungsi distribusi kumulatif dari distribusi Weibull sebagai distribusi campuran adalah:

$F^{*}\left(x_{i}\right)=1-e^{-0,0004 \sqrt{101500}}=0,1197$.

Nilai taksiran fungsi distribusi kumulatif dari distribusi Weibull sebagai distribusi campuran untuk data yang lainnya dihitung dengan cara yang sama sebagaimana di atas. Selanjutnya Kolom (5) merupakan nilai dari nilai fungsi empiris yang didapat dari kolom (3) dikurangin nilai fungsi distribusi kumulatif yang didapat kolom (4). 
Tabel 3 Hasil Perhitungan untuk Uji Kolmogorov-Smirnov Data Besar Klaim

\begin{tabular}{ccccc}
\hline $\boldsymbol{I}$ & $\boldsymbol{x}_{\boldsymbol{i}}$ & $F_{\mathrm{w}}\left(\boldsymbol{x}_{\boldsymbol{i}}\right)$ & $\boldsymbol{F}^{*}\left(\boldsymbol{x}_{\boldsymbol{i}}\right)$ & $\boldsymbol{F}_{\boldsymbol{n}}\left(\boldsymbol{x}_{\boldsymbol{i}}\right)-\boldsymbol{F}^{*}\left(\boldsymbol{x}_{\boldsymbol{i}}\right)$ \\
\hline $\mathbf{1}$ & 101500 & 0,0152 & 0,1197 & $-0,1045$ \\
$\mathbf{2}$ & 110000 & 0,0303 & 0,1242 & $-0,0939$ \\
$\mathbf{3}$ & 115000 & 0,0455 & 0,1268 & $-0,0814$ \\
$\mathbf{4}$ & 125000 & 0,0606 & 0,1319 & $-0,0713$ \\
$\mathbf{5}$ & 147000 & 0,0758 & 0,1422 & $-0,0664$ \\
$\mathbf{6}$ & 168000 & 0,0909 & 0,1512 & $-0,0603$ \\
$\mathbf{7}$ & 171500 & 0,1061 & 0,1527 & $-0,0466$ \\
$\mathbf{8}$ & 210000 & 0,1212 & 0,1675 & $-0,0463$ \\
$\mathbf{9}$ & 226000 & 0,1364 & 0,1732 & $-0,0368$ \\
$\mathbf{1 0}$ & 300000 & 0,1515 & 0,1967 & $-0,0452$ \\
$\vdots$ & $\vdots$ & $\vdots$ & $\vdots$ & $\vdots$ \\
$\mathbf{6 6}$ & 80340000 & 1,0000 & 0,9723 & 0,0277 \\
\hline
\end{tabular}

Dengan bantuan hasil perhitungan yang ada pada Tabel 3, dapat dihitung statistik uji Kolmogorov-Smirnov yaitu:

$$
D=\max _{1 \leq i \leq n}\left|F_{n}\left(x_{i}\right)-F^{*}\left(x_{i}\right)\right|=0,1411 \text {. }
$$

Dari hasil perhitungan diperoleh nilai statistik uji Kolmogorov-Smirnov yaitu $D=0,1411$. Dengan taraf nyata, $\alpha=5 \%$, nilai kritisnya adalah $\frac{1,36}{\sqrt{66}}=0,1674$. Terlihat bahwa nilai statistik uji Kolmogorov-Smirnov di atas lebih kecil dibandingkan dengan nilai kritisnya, sehingga hipotesis nol diterima dan disimpulkan bahwa data besar klaim tertanggung asuransi kendaraan bermotor di Indonesia kategori 8 wilayah 3 berasal dari populasi yang berdistribusi Weibull sebagai distribusi campuran.

\subsection{Perhitungan Premi Sistem Bonus Malus Optimal}

Penentuan premi sistem bonus malus optimal diperoleh dengan menggunakan komponen frekuensi klaim dan komponen besar klaim. Data frekuensi klaim berdistribusi binomial negatif dengan nilai taksiran parameter $\hat{r}=0,04731$ dan $\hat{\tau}=4,26617$ dan data besar klaim berdistribusi Weibull dengan nilai taksiran parameter $\hat{c}=0,0004$.

Perhitungan premi risiko pada periode $t+1$ dengan sistem bonus malus optimal diperoleh dengan menggunakan Persamaan (19), dan saat besar kerugian $=0$ atau pada saat tidak ada klaim yang diajuakan $(K=0)$ premi risiko dihitung menggunakan Persamaan (20). Pada Tabel 4 dapat dilihat perhitungan premi dengan sistem bonus malus optimal dengan total besar klaim dalam 1 tahun, $\sum_{i=1}^{K} x_{i}=500.000$.

Tabel 4 Nilai Premi Berdasarkan Frekuensi Klaim dan Besar Klaim (dalam Rupiah)

\begin{tabular}{ccccc}
\hline Tahun & \multicolumn{4}{c}{ Banyaknya Klaim $(K)$} \\
\cline { 2 - 5 }$(t)$ & 0 & 1 & 2 & 3 \\
\hline 0 & 138.737 & 703.156 & 1.374 .524 & 2.045 .891 \\
1 & 31.789 & 590.942 & 1.155 .167 & 1.719 .393 \\
2 & 26.716 & 509.614 & 996.189 & 1.482 .763 \\
3 & 23.039 & 447.963 & 875.675 & 1.303 .386 \\
4 & 20.252 & 399.619 & 781.172 & 1.162 .725 \\
5 & 18.067 & & & \\
\hline
\end{tabular}

Penjelasan untuk Tabel 4 di atas adalah sebagai berikut. Sebagai contoh untuk baris $t=$ 1, jika seorang pemegang polis asuransi dengan premi awal Rp. 138.737 dan tidak mengajukan klaim dalam satu tahun masa asuransinya, maka pemegang polis tersebut akan mendapatkan bonus berupa penurunan harga premi yang harus dibayarkan di tahun kedua masa asuransinya yaitu Rp. 31.789 (dengan catatan apabila pemegang polis memperpanjang polis asuransinya). Jika pemegang polis asuransi mengajukan satu kali klaim dalam satu 
tahun masa asuransinya dengan total besar klaim sebesar Rp. 500.000, maka premi yang harus dibayarkan pada tahun kedua masa asuransinya adalah sebesar Rp. 703.156. Jika pemegang polis mengajukan dua kali klaim dalam satu tahun masa asuransinya dengan total besar klaim sebesar Rp. 500.000, maka premi yang harus dibayarkan pada tahun kedua masa asuransinya adalah Rp. 1.374.524.

Penjelasan untuk $t=2$, dengan premi pada tahun pertama sebesar Rp. 138.737, jika seorang pemegang polis tidak mengajukan klaim dalam dua tahun masa asuransinya, maka premi yang harus dibayarkan pada tahun ketiga masa asuransinya adalah Rp. 26.716. Jika pemegang polis mengajukan klaim satu kali klaim selama dua tahun masa asuransinya dengan total besar klaim sebesar Rp. 500.000, maka premi yang harus dibayarkan pada tahun ketiga masa asuransinya adalah Rp. 590.942.

\section{KESIMPULAN}

Dalam penelitian ini telah dilakukan penerapan perhitungan premi murni pada sistem bonus malus dimana frekuensi klaim berdistribusi binomial negatif dan besar klaim berdistribusi Weibull pada data asuransi kendaraan bermotor kategori 8 wilayah 3 di Indonesia. Hasil perhitungan menunjukkan bahwa premi dengan sistem bonus malus secara optimal dirasa cukup adil karena premi yang dibayarkan oleh pemegang polis asuransi yang melakukan perpanjangan polis pada tahun berikutnya sebanding dengan risiko yang dihadapinya, dimana premi yang harus dibayarkan oleh setiap pemegang polis didasarkan pada sejarah klaim masa lalu, dalam hal ini frekuensi klaim dan besar klaim.

\section{DAFTAR PUSTAKA}

Febriana (2012). Pelaksanaan Asuransi Kendaraan Bermotor Terhadap Kepentingan Pihak Ketiga Studi Kasus PT Asuransi Indrapura Cab. Bandar Lampung . Lampung: Jurusan Hukum Perdata, Fakultas Hukum, Universitas Lampung.

Kementrian Keuangan. (2007). Peraturan Menteri Keuangan Nomor 74/PMK.010/2007: Tentang Penyelenggaraan Pertanggungan Asuransi pada Lini Usaha Asuransi Kendaraan Bermotor. Jakarta: Kemenkeu.

Kinasih, I. P. (2019). Weibull Parameter Estimation using Bisection and Genetic Alghoritm. 26-46.

Kitab Undang-Undang Hukum Dagang (KUHD). Bab IX Tentang Asuransi atau Pertanggungan pada Umumnya, Pasal 246.

Klugman, S. A., Panjer, H. H., \& Willmot, G. E. (2012). Loss Model From Data To Decisions. New York: Willey Interscience.

Mutaqin, A. K., \& Komarudin. (2008). Perhitungan Premi untuk Asuransi Kendaraan Bermotor Berdasarkan Sejarah Frekuensi Klaim Pemegang Polis Menggunakan Analisis Bayes. Phytagoras, 47-55.

Otoritas Jasa Keuangan. (2017). Penetapan Tarif Premi atau Kontribusi pada Lini Usaha Asuransi Harta Benda atau Asuransi Kendaraan Bermotor . Jakarta: Surat Edaran Otoritas Jasa Keuangan No. 7/SEOJK.05/2017.

Santi, D. N., Purnaba, \& Mangku. (2016). Bonus-Malus System with the Claim Frequency Distribution is Geometric and Severity Distribution is Truncated Weibull. Iop Science.

Undang- Undang Republik Indonesia. (2014). UU RI. Nomor 40 Tahun 2014: Tentang Perasuransian. Jakarta. 